\title{
ACUTE PAIN TREATMENT AT DEPARTMENT OF TRAUMATOLOGY
}

\author{
${ }^{1}$ Kováčová B. $-{ }^{1}$ Foltánová T. $-{ }^{2}$ Kónya $\breve{S} .-{ }^{3}$ D̆urišsová A. \\ ${ }^{1}$ Comenius University in Bratislava, Faculty of Pharmacy, Department of Pharmacology \\ and Toxicology \\ ${ }^{2}$ Teaching Hospital Nitra, Trauma and Orthopaedic Surgery Department \\ ${ }^{3}$ Teaching Hospital Nitra, Department of Neonatology
}

The aim of this retrospective study was to characterize the acute pain management in patients admitted to Department of Traumatology and to identify the efficacy of analgesic pharmacotherapy.

The study involved 83 patients divided into two groups: 52 patients (63\%) in Group 1 underwent operation; the remaining 31 patients (37\%) in Group 2 had conservative treatment. The characteristics of the patients (diagnosis, analgesic therapy, age, comorbidities, drugs used during hospitalisation, analgesic efficacy) were obtained from electronic database and medical reports by the hospital. Therapy during the first seven days of hospitalisation and the recommended therapy after discharging home were analysed. Records of drug adverse reactions during the whole hospitalisation were monitored.

Metamizol was the most frequently prescribed as a primal analgesic. Adequate analgesia solely by metamizol was reached in $20 \%$ of all patients; the remaining $80 \%$ required increased doses or combination with another analgesic. Metamizol was combined mainly with tramadol, morphine or pethidine. Our study proved metamizol to be an effective analgesic. No clinical manifestation of agranulocytosis was observed in this study.

Keywords: acute pain - traumatology - metamizol - analgesic - hospitalisation

\section{INTRODUCTION}

Despite the medical progress and the existence of plenty of analgesics, many works call attention to inadequate relief of acute postoperative pain (Ševčík, 2008, Bandolier Extra, 2003). Persisting acute pain as a consequence of failed analgesia leads to physical and mental strain of patient and has negative impact on his/her recovery. Memory of central 
nervous system and neuroplasticity are the main mechanisms of transformation of acute pain to chronic pain, which, however, is difficult to treat and puts a strain on both patient and society.

The stress response following to trauma and surgical intervention brings metabolic disbalance and causes a state known as "ebb and flow" characterized by increased secretion of pituitary hormones, which triggers physiological and pathophysiological cascades (Desborough, 2000).

The situation is far more complicated in seniors and chronically ill persons, who are supposed to have disturbed metabolism. Choice of suitable analgesic is therefore guided by pain intensity and patient's characteristics - physiological condition, comorbidities, drugs used concurrently and response to treatment.

\section{EXPERIMENTAL PART}

The retrospective study includes the patients admitted to Department of Traumatology Teaching Hospital Nitra in April 2012 and were provided acute conservative or surgical care after trauma of musculoskeletal system, head, chest or spine. In case of polytraumatic patient, each trauma was listed. The patients were divided into two groups: patients undergoing operation (Group 1) and patients with conservative treatment (Group 2).

The study analyses the analgesic therapy during the first seven days after admission at Department of Traumatology. Main diagnosis of hospitalisation, detailed track of analgesic therapy (drug, dose, route and time of administration), comorbidities and drugs used concurrently were the observed data. Pain management was evaluated on the basis of prescribed analgesic and any other analgesics required by patient when feeling pain. If no additional analgesic were required, the pain management was considered to be adequate. The patients without analgesic therapy and patients hospitalised because of previously planned chronic diagnoses treatment were excluded from the study. All data were obtained from electronic database and medical reports of Teaching Hospital Nitra.

\section{RESULTS}

The study group included 83 patients: 34 men (41\%) and 49 women (59\%) with average age 53.8 years $(2-90)$.

The diagnosis were divided into five groups: injury of upper limb (17\%), lower limb $(46 \%)$, head $(18 \%)$, spine $(16 \%)$, else $(8 \%)$. The most frequent cause of hospitalisation was injury of the lower limb - especially fracture of femoral neck in women aged 65 years and older.

Group 1 and Group 2 involved 53 (63\%) and 31 patients (37\%), respectively. In Group 1, operation was carried out within seven days after admission to hospital, with the exception of two patients (operation on day 9 and 17). Patients with chronic disorder of musculoskeletal system (13\%) and patients on oncological 
treatment $(0.02 \%)$ continued their chronic analgesic therapy. Polypharmacy, i.e. using 4 or more medications, was observed in $28(34 \%)$ patients. Cardiovascular diseases (42\%), diabetes mellitus (16\%) and chronic musculoskeletal disorders $(13 \%)$ were the most frequent comorbidities.

The most frequently prescribed analgesic was metamizol $500 \mathrm{mg}, 3$ or 4 times daily administered in parenteral (p.e.) or peroral (p.o.) route. Adequate analgesia by metamizol prescription was experienced in $20 \%$ of all patients. In case of inadequate analgesia, additional metamizol dose or another analgesic was used to strengthen the metamizol effect. As for opioids, the most frequently used was tramadol $50 \mathrm{mg}$ (p.e. or p.o.); in cases of very strong pain it was morphin $10 \mathrm{mg}$ (p.e.) or pethidin (p.e.).

The analgesic therapy during the first seven days of hospitalisation is listed in Table 1.

Table 1. The analgesic therapy during the first seven days of hospitalisation

\begin{tabular}{l|cc}
\hline \multicolumn{1}{c}{ Drug } & $\begin{array}{c}\text { \% of patients in Group 1 } \\
(\mathrm{n}=52)\end{array}$ & \% patients in Group 2 $(\mathrm{n}=31)$ \\
\hline metamizol & 94.2 & 93.5 \\
tramadol & 46.2 & 29.0 \\
morphine & 25.0 & 6.4 \\
pethidin & 11.5 & 0.0 \\
flurbiprofen & 7.7 & 3.2 \\
ibuprofen & 5.8 & 9.7 \\
tolperisone & 3.8 & 9.7 \\
\hline
\end{tabular}

Metamizol was the most frequently used analgesic in both Group 1 (94\%) and Group 2 (93\%). Patients in Group 2 required smaller amount of analgesics than patients in Group 1. The greatest part of therapy was covered by metamizol monotherapy. Number of patients requiring analgesics decreased gradually during first seven days of hospitalisation: monotherapy increased from $15 \%$ to $55 \%$ and from $6 \%$ to $71 \%$ in Group 1 and Group 2, respectively (Figures 1 and 2).

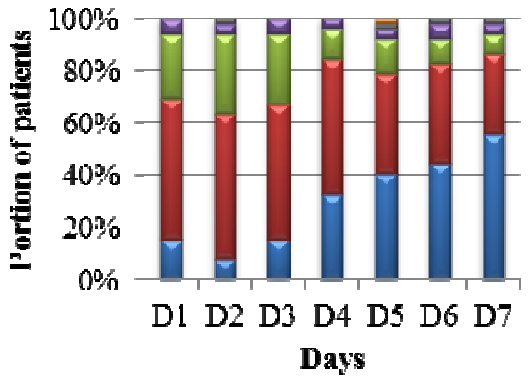

$\square 0 \square 1 \square 2 \square 3 \square 4 \square 5$

Figure 1. Number of analgesics during the first 7 days of hospitalisation in Group 1

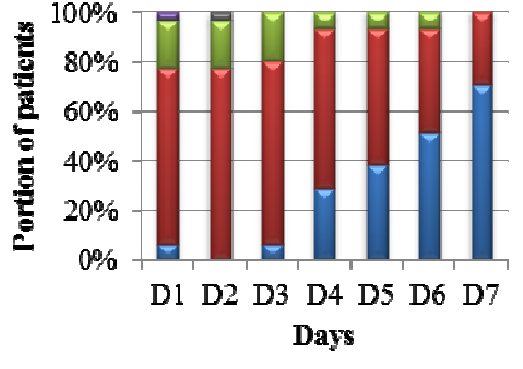

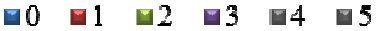

Figure 2. Number of analgesics during the first 7 days of hospitalisation in Group 2 
Metamizol proved effective analgesic; adequate analgesia by metamizol was experienced also in an oncologic patient chronically on oxycodone $20 \mathrm{mg}(2 x 1$ p.o.) and two patients with musculoskeletal diseases chronically on diclofenac $75 \mathrm{mg}$ (1 patient: $2 \times 1$ p.o.) or flupirtine $100 \mathrm{mg}$ (1 patient: $3 \times 1$ p.o.).

Monotherapy, mainly by metamizol, prevailed in the recommended therapy after discharge (Figures 3 and 4), duration of home treatment was individual, according to need.

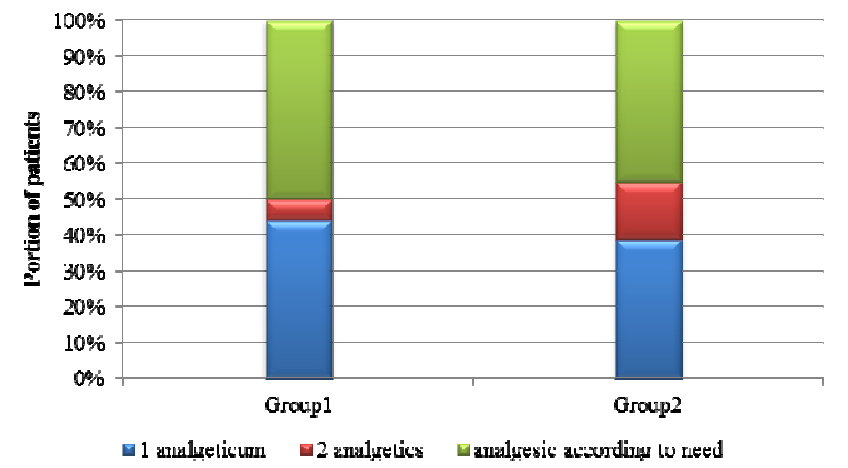

Figure 3. Recommended therapy after discharge

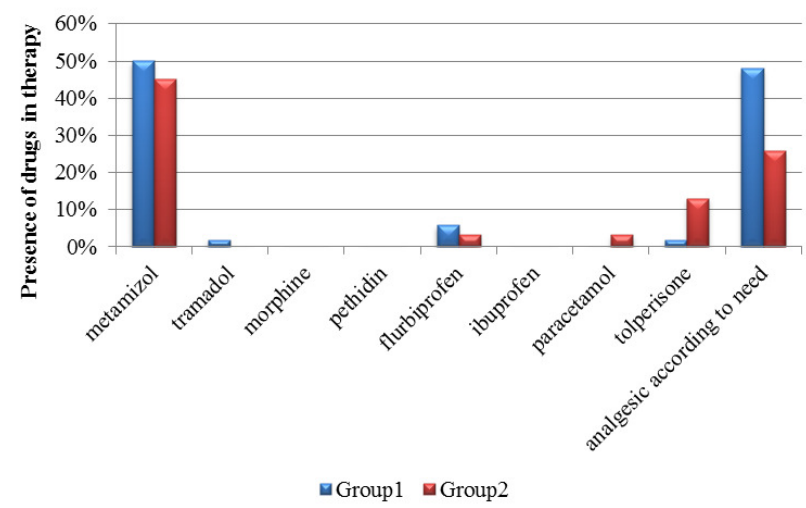

Figure 4. Number of analgesic in recommended therapy after discharge

\section{DISCUSSION}

Choice of analgesic is guided by Analgesic ladder designed by WHO. Non-steroidal anti-inflammatory drugs (NSAIDs) or analgesics-antipyretics are recommended for mild pain. NSAIDs have great analgesic potential, but they also have limits: they prolong haemocoagulation time and increase the risk of gastrointestinal bleeding. In traumatology, inpatients are administered low-weight molecular heparins (LWMHs) to prevent and cure thromboembolic events and their doses are precisely adjusted. It is 
not recommended to combine NSAIDs with LWMHs as it may cause increased bleeding (SPC Clexane, Fragmin, Fraxiparine). NSAIDs inhibit cyclooxygenase (COX) in gastric epithelium and hence prostaglandin synthesis and cause damage by gastric juice. Moreover, acid NSAIDs have topical irritant effect on gastric mucosa. The reason is their accumulation in gastric mucosa cells, uncoupling oxidative mitochondrial phosphorylation resulting in diminished cellular ATP production and accumulation of calcium and reactive oxygen species (Hinz, 2007).

From this point of view, analgesic-antipyretic drugs like paracetamol (acetaminophen) and metamizol (dipyrone) are the safer alternatives. Paracetamol is a drug of choice in seniors and pregnant or breastfeeding women. It does not cause gastrointestinal toxicity or interference with long-term oral anticoagulant therapy. However, it is recommended to examine prothrombin time, as it may inhibit a warfarin degradation (SPC Paralen; Bell, 1998). Metamizol is a pyrazolinone derivate with analgesic, antipyretic and spasmolytic (but no anticholinergic) effect and a weak inhibitory effect on COX-1 and COX-2. Metamizol is a prodrug; in gastric juice, it is hydrolyzed to its main metabolite, 4-methyl-amino-antipyrine (MAA), and later to 4-amino-antipyrine (AA). It works by direct blockade of the peripheral inflammatory hyperalgesia as well as by spinal effect in sensory neurons (Chaparro, 2011). Unlike NSAIDs, metamizol lacks acidity and therefore does not irritate gastric mucosa (Hinz, 2007). On the other hand, use of metamizol is associated with agranulocytosis which caused its withdrawal in many countries (USA, Canada, Japan, Sweden, UK) in the 70s of the last century (Chaparro, 2011). By the last SPC in force, incidence of agranulocytosis is very rare. Agranulocytosis is manifested as a sore throat, fever, shivering (SPC Quarelin), inflammatory mucosal lesions - for example in mouth, throat, anorectum and genital (SPC Novalgin). Information about agranulocytosis incidence varies (Bensenor, 2001); it ranges from 1:30,000 to 1: 500,000 (Graff, 2007) or even to 1:1,000,000 (Noskova, 2011).

In our study, metamizol was the most frequently used analgesic (94\% in Group 1,93\% in Group 2) and proved very good analgesia. Number of neutrophils was not observed, but clinical manifestation of agranulocytosis was not noticed. Within the last 5 years (January 2007 - June 2012), State Institute for Drug Control (SIDC) in Slovakia received no report of confirmed agranulocytosis related to metamizol, but clinical manifestation in some of reported cases implies it (shivering and fever in $6 \%$ of reported cases; n=32) ( personal communication with MUDr. Ružena Kamenská, SIDC, Drug Safety and Clinical Trials Section, June 19, 2012). During the whole time of hospitalisation, each patient was observed for incidence of any known adverse reactions related to metamizol. No such cases were noticed.

By the last SPC in force, agranulocytosis incidence is not dose-dependent and may appear spontaneously at any time during the treatment (SPC Novalgin).

Use of metamizol should be considered in patients on antiaggregation therapy with acetylsalicylic acid (ASA). MAA forms a strong hydrogen bond with COX-1, thereby prevents its irreversible acetylation by ASA and hence breaks antiagregation effect of ASA (Hohlfeld, 2007).

In our study, in case of combined analgesia, metamizol was coadministered with opioid analgesic. The weak opioid, tramadol, was administered to $46 \%$ and $29 \%$ patients in Group 1 and Group 2, respectively; strong morphine was administered to $25 \%$ and $6 \%$ 
patients in Group 1 and Group 2, respectively. Opioid was prescribed as a primal analgesic in no one patient; it was administered on patient's demand in case of very strong pain.

Opioid analgesics are reserved for strong or cancer pain. Digestive problems (nausea, vomiting, slower motility) may occur, especially in older and immobile patients.

\section{CONCLUSION}

In our study, acute pain on Department of Traumatology was very well managed by metamizol. Our results therefore confirmed that its effect is comparable to paracetamol, ibuprofen and is nearly similar to opioid analgesia (Fendrich, 2000, Ben Bassat, 1959). Its good efficacy and great popularity is proven by the fact, that a monocomponent medicine containing metamizol was the second most prescribed medicine in Slovakia in 2011 (National Health Information Center). Its withdrawal in many large countries makes clinical trials more difficult and retards obtaining of new information. Nowadays, it is available in some countries in Europe (Czech Republic, Germany, Spain, Russia), Africa and South America (Chaparro, 2012, Hinz, 2007). In Slovakia, metamizol is available as a monocomponent analgesic or combined with spasmolytics (Table 2). All the medicines containing metamizol are available on prescription only.

Table 2. Medicines containing metamizol authorised in SR

\begin{tabular}{|c|c|c|c|}
\hline Medicine & Composition & $\begin{array}{l}\text { Pharmaceutical } \\
\text { form }\end{array}$ & $\begin{array}{c}\text { First } \\
\text { authorisation } \\
\text { in SR } \\
\end{array}$ \\
\hline NOVALGIN & metamizol $500 \mathrm{mg}$ & tbl flm, sol inj & 1995 \\
\hline QUARELIN & $\begin{array}{l}\text { metamizol } 400 \mathrm{mg} \text {, } \\
\text { caffeine } 60 \mathrm{mg}, \\
\text { drotaverine } 40 \mathrm{mg}\end{array}$ & tbl & 1992 \\
\hline ALGIFEN & $\begin{array}{l}\text { metamizol } 500 \mathrm{mg} \text {, } \\
\text { pitofenone } 5.25 \\
\mathrm{mg} \text {, fenpiverine } \\
0.1 \mathrm{mg}\end{array}$ & tbl & 1990 \\
\hline ALGIFEN NEO & $\begin{array}{l}\text { metamizol } 500 \mathrm{mg} \text {, } \\
\text { pitofenone } 5 \mathrm{mg}\end{array}$ & gto por & 2003 \\
\hline ALGIFEN SUP & $\begin{array}{l}\text { metamizol } 1 \mathrm{~g} \text {, } \\
\text { pitofenone } 10 \mathrm{mg} \text {, } \\
\text { fenpiverine } 0.1 \mathrm{mg}\end{array}$ & sup & 1990 \\
\hline ANALGIN & $\begin{array}{l}\text { metamizol } 2,500 \\
\mathrm{mg}, \text { pitofenone } 10 \\
\mathrm{mg} \text {, fenpiverine } \\
0.1 \mathrm{mg}\end{array}$ & sol inj & 1992 \\
\hline
\end{tabular}




\section{ACKNOWLEDGMENTS}

The study was supported by Grant of Pharmaceutical Faculty Comenius University FaF UK/2/2012. We also thank Teaching Hospital in Nitra. as well as State Institute of drug control.

\section{REFERENCES}

Bandolier Extra. Evidence-based health care. Acute Pain. 2003. http://www.medicine.ox.ac.uk/bandolier/Extraforbando/APain.pdf

Bell WR. Acetaminophen and warfarin. Undesirable synergy. JAMA. 1998; 279(9):702-703.

Ben-Bassat J, Peretz E, Sulman FG. Analgesimetry and ranking of analgesic drug by the receptacle method. Arch Int Pharmacodyn. 1959; 122:434-447.

Bensenor IM. To use or not to use dipyrone? Or maybe, Central Station versus ER? That is the question. Sao Paulo Med. J. 2001; 119(6):190-191.

Desborough JP. The stress response to trauma and surgery. Br J Anaesth. 2000; 85:109117.

Fendrich Z. Metamizol - a New Effective Analgesic with a Long History: A Survey of Pharmacology and Clinical Applications. Čas. Lék. Čes. 2000; 139(14):440-444.

Graff J, Arabmotlagh M, Cheung R, Geisslinger G, Harder S. Effects of Parecoxib and Dipyrone on Platelet Aggregation in Patients Undergoing Meniscectomy: A DoubleBlind, Randomized, Parallel-Group Study. Clin Ther. 2007; 29:438-447.

Hinz B. et al. Dipyrone elicits substantial inhibition of peripheral cyclooxygenases in humans: new insights into the pharmacology of an old analgesic. The FASEB J. 2007; 21:2343-2351.

Hohlfeld T. et al. Pyrazolinone analgesics prevent the antiplatelet effect of aspirin and preserve human platelet thromboxane synthesis. J Thromb Haemost. 2008; 6:166-173.

Chaparro LE, Lezcano W, Alvarez HD, Joaqui W. Analgesic Effectiveness of Dipyrone (Metamizol) for Postoperative Pain after Herniorrhaphy: A Randomized, Double-Blind, Dose-Response Study. Pain Practice. 2011;12 (2):142-147.

National health information center. Medical statistics. TOP 50. http://www.nczisk.sk/Documents/zverejnovanie_zakon_lieky/TOP50_Lieky_2011.pdf 
Nosková P. How to manage acute pain fast. Interní Med. 2011; 13 (9):360-364. In Czech

SPC Clexane, Fragmin, Fraxiparine, Paralen, Quarelin, Novalgin: http://www.sukl.sk/sk/databazy-a-servis/databazy/vyhladavanie-v-databazeregistrovanych-liekov?page_id=242 Accessed on October 12,2012

Ševčík P. et al.The treatment of acute postoperative pain. The guideline of Czech Society of Anaesthesiology and Intensive Medicine JEP (ČSARIM) 2008 In Czech.

Registered: October 18, 2012

Accepted: October 30, 2012

Mgr. Barbora Kováčová

Comenius University in Bratislava

Faculty of Pharmacy

Odbojárov 10

832 32, Bratislava

Slovak Republic

kovacova@fpharm.uniba.sk

\title{
LIEČBA AKÚTNEJ BOLESTI NA ODDELENÍ TRAUMATOLÓGIE
}

\author{
${ }^{1}$ Kováčová B. $-{ }^{1}$ Foltánová T. $-{ }^{2}$ Kónya $\breve{S} .-{ }^{3}$ D̆urišová $A$. \\ ${ }^{1}$ Univerzita Komenského v Bratislave, Farmaceutická fakulta, \\ Katedra farmakológie a toxikológie, \\ ${ }^{2}$ Fakultná nemocnica, Nitra, Klinika úrazovej chirurgie a ortopédie \\ ${ }^{3}$ Fakultná nemocnica Klinika novorodencov, detí a dorastu
}

Ciel'om tejto retrospektívnej štúdie bolo charakterizovat' zvládanie akútnej bolesti u hospitalizovaných pacientov na oddelení traumatológie a identifikovat' úspešnost' analgetickej farmakoterapie.

Sledovaný súbor tvorilo 83 pacientov, z toho 52 pacientov $(63 \%)$ podstúpilo operáciu a 31 pacientov (37\%) bolo ošetrených konzervatívne. Charakteristiky pacientov (príčina hospitalizácie, analgetická terapia, vek, komorbidity, súčasne užívané liečivá, reakcia na analgetickú liečbu) sme získali z elektronickej databázy a chorobopisov nemocnice. Analyzovali sme terapiu počas prvých 7 dní hospitalizácie a odporúčanú terapiu do domáceho ošetrenia po ukončení hospitalizácie. Záznamy o výskyte nežiaducich reakcií sme sledovali počas celej doby hospitalizácie pacientov.

Najčastejšie primárne ordinovaným analgetikom bol metamizol. Dostatočná analgézia podl’a základnej ordinácie výlučne (v monoterapii) metamizolom sa dosiahla u $20 \%$ zo všetkých pacientov, 80 \% pacientov si vyžadovalo zvýšenie dávky alebo kombináciu s iným analgetikom. Metamizol sa najčastejšie kombinoval s tramadolom, morfinom alebo petidínom. V našej štúdii sa metamizol ukázal ako účinné analgetikum. Zároveň sme nezaznamenali výskyt klinických prejavov agranulocytózy.

Acta Fac. Pharm. Univ. Comen. LIX, 2012, (2), p. 28-35. 